\title{
Fibronectins, Their Fibrillogenesis, and In Vivo Functions
}

\author{
Jean E. Schwarzbauer ${ }^{1}$ and Douglas W. DeSimone ${ }^{2}$ \\ ${ }^{1}$ Department of Molecular Biology, Princeton University, Princeton, New Jersey 08544 \\ ${ }^{2}$ Department of Cell Biology, University of Virginia, Charlottesville, Virginia 22908 \\ Correspondence: jschwarz@princeton.edu
}

Fibronectin ( $\mathrm{FN}$ ) is a multidomain protein with the ability to bind simultaneously to cell surface receptors, collagen, proteoglycans, and other FN molecules. Many of these domains and interactions are also involved in the assembly of $\mathrm{FN}$ dimers into a multimeric fibrillar matrix. When, where, and how FN binds to its various partners must be controlled and coordinated during fibrillogenesis. Steps in the process of FN fibrillogenesis including FN self-association, receptor activities, and intracellular pathways have been under intense investigation for years. In this review, the domain organization of FN including the extra domains and variable region that are controlled by alternative splicing are described. We discuss how $\mathrm{FN}-\mathrm{FN}$ and cell-FN interactions play essential roles in the initiation and progression of matrix assembly using complementary results from cell culture and embryonic model systems that have enhanced our understanding of this process.

\begin{abstract}
$A s$ a ubiquitous component of the extraAcellular matrix (ECM), fibronectin (FN) provides essential connections to cells through integrins and other receptors and regulates cell adhesion, migration, and differentiation. FN is secreted as a large dimeric glycoprotein with subunits that range in size from $230 \mathrm{kDa}$ to $270 \mathrm{kDa}$ (Mosher 1989; Hynes 1990). Variation in subunit size depends primarily on alternative splicing. FN was first isolated from blood more than 60 years ago (Edsall 1978), and this form is called plasma FN. The other major form, called cellular FN, is abundant in the fibrillar matrices of most tissues. Although FN is probably best known for promoting attachment of cells to surfaces, this multidomain protein has many interesting
\end{abstract}

structural features and functional roles beyond cell adhesion.

$\mathrm{FN}$ is composed of three different types of modules termed type I, II, and III repeats (Fig. 1) (Petersen et al. 1983; Hynes 1990). These repeats have distinct structures. Although the conformations of type I and type II repeats are maintained by pairs of intramodule disulfide bonds, the type III repeat is a 7-stranded $\beta$-barrel structure that lacks disulfide bonds (Main et al. 1992; Leahy et al. 1996, 1992) and, therefore, can undergo conformational changes. FN type III repeats are widely distributed among animal, bacterial, and plant proteins and are found in both extracellular and intracellular proteins (Bork and Doolittle 1992; Tsyguelnaia and Doolittle 1998).

Editors: Richard O. Hynes and Kenneth M. Yamada

Additional Perspectives on Extracellular Matrix Biology available at www.cshperspectives.org

Copyright (C) 2011 Cold Spring Harbor Laboratory Press; all rights reserved; doi: 10.1101/cshperspect.a005041

Cite this article as Cold Spring Harb Perspect Biol 2011;3:a005041 
J.E. Schwarzbauer and D.W. DeSimone

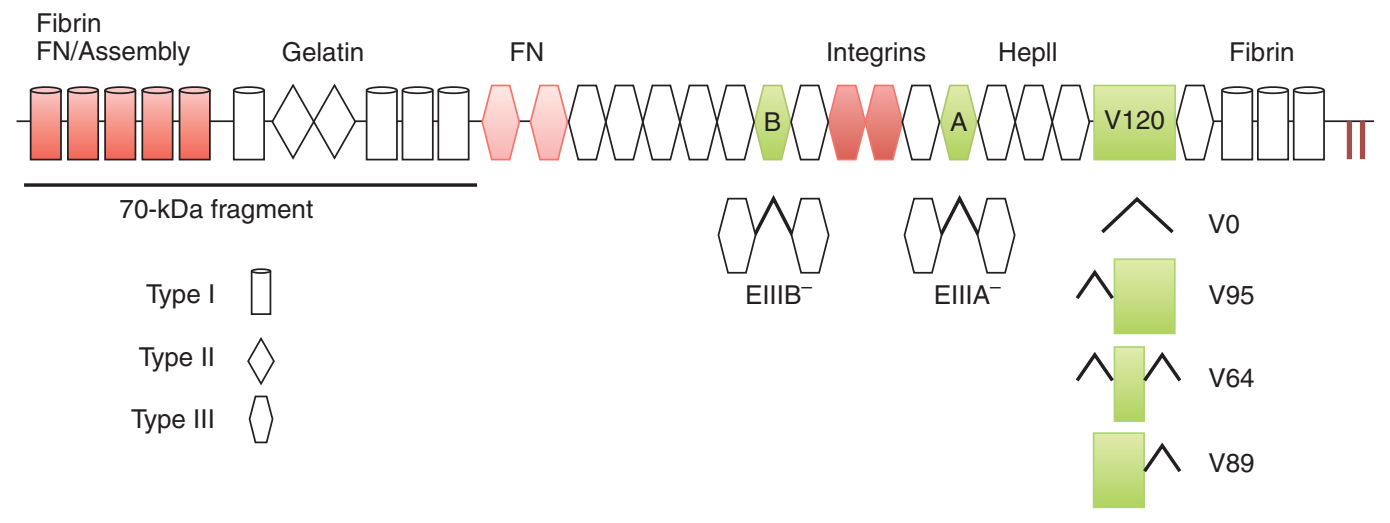

Figure 1. FN domain organization and isoforms. Each FN monomer has a modular structure consisting of 12 type I repeats (cylinders), 2 type II repeats (diamonds), and 15 constitutive type III repeats (hexagons). Two additional type III repeats (EIIIA and EIIIB, green) are included or omitted by alternative splicing. The third region of alternative splicing, the V region (green box), is included (V120), excluded (V0), or partially included (V95, V64, V89). Sets of modules comprise domains for binding to other extracellular molecules as indicated. Domains required for fibrillogenesis are in red: the assembly domain (repeats $\mathrm{I}_{1-5}$ ) binds $\mathrm{FN} \mathrm{III}_{9-10}$ contains the RGD and synergy sequences for integrin binding, and the carboxy-terminal cysteines form the disulfide-bonded FN dimer $(\|)$. The $\mathrm{III}_{1-2}$ domain (light red) has two FN binding sites that are important for fibrillogenesis. The amino-terminal 70-kDa fragment contains assembly and gelatin-binding domains and is routinely used in FN binding and matrix assembly studies.

Sets of adjacent modules form binding domains for a variety of proteins and carbohydrates (Fig. 1). ECM proteins, including FN, bind to cells via integrin receptors, $\alpha \beta$ heterodimers with two transmembrane subunits (Hynes 2002). FN-binding integrins have specificity for one of the two cell-binding sites within FN, either the RGD-dependent cellbinding domain in $\mathrm{III}_{10}$ (Pierschbacher and Ruoslahti 1984) or the CS1 segment of the alternatively spliced $\mathrm{V}$ region (IIICS) (Wayner et al. 1989; Guan and Hynes 1990). Some integrins require a synergy sequence in repeat $\mathrm{III}_{9}$ for maximal interactions with FN (Aota et al. 1994; Bowditch et al. 1994). Another family of cell surface receptors is the syndecans, singlechain transmembrane proteoglycans (Couchman 2010). Syndecans use their glycosaminoglycan (GAG) chains to interact with FN at its carboxy-terminal heparin-binding (HepII) domain (Fig. 1) (Saunders and Bernfield 1988; Woods et al. 2000), which binds to heparin, heparan sulfate, and chondroitin sulfate GAGs (Hynes 1990; Barkalow and Schwarzbauer 1994). Syndecan binding to the HepII domain enhances integrin-mediated cell spreading and intracellular signaling, suggesting that syndecans act as coreceptors with integrins in cellFN binding (Woods and Couchman 1998; Morgan et al. 2007).

A major site for FN self-association is within the amino-terminal assembly domain spanning the first five type I repeats $\left(\mathrm{I}_{1-5}\right)$ (Fig. 1) (McKeown-Longo and Mosher 1985; McDonald et al. 1987; Schwarzbauer 1991b; Sottile et al. 1991). This domain plays an essential role in FN fibrillogenesis. As a major blood protein, FN interacts with fibrin during blood coagulation, also using the $\mathrm{I}_{1-5}$ domain (Mosher 1989; Hynes 1990). As fibrin polymerizes, factor XIII transglutaminase covalently cross-links glutamine residues near the amino terminus of FN to fibrin $\alpha$ chains (Mosher 1975; Corbett et al. 1997). The amino-terminal domain has multiple binding partners in addition to FN and fibrin; these include heparin, S. aureus, and other bacteria, thrombospondin-1, and tenascin-C (Hynes 1990; Ingham et al. 2004; Schwarz-Linek et al. 2006). Adjacent to this domain is the gelatin/collagen-binding domain 
composed of type I and type II modules (Ingham et al. 1988). This domain also binds to tissue transglutaminase (Radek et al. 1993) and fibrillin-1 (Sabatier et al. 2009). Within the 15 type III repeats reside several FN binding sites that interact with the amino-terminal assembly domain as well as three sites of alternative splicing that generate multiple isoforms. At the carboxyl terminus is a pair of cysteine residues that form the FN dimer through antiparallel disulfide bonds (Hynes 1990). This dimerization may be facilitated by disulfide isomerase activity located in the last set of type I repeats (Langenbach and Sottile 1999).

The diverse set of binding domains provides $\mathrm{FN}$ with the ability to interact simultaneously with other FN molecules, other ECM components (e.g., collagens and proteoglycans), cell surface receptors, and extracellular enzymes (Pankov and Yamada 2002; Fogelgren et al. 2005; Hynes 2009; Singh et al. 2010). Multitasking by FN probably underlies its essential role during embryogenesis (George et al. 1993). Furthermore, FN's interactions can be modulated by exposure or sequestration of its binding sites within matrix fibrils, through the presence of ECM proteins that bind to $\mathrm{FN}$, or through variation in structure by alternative splicing.

\section{DERIVATION AND FUNCTIONS OF ALTERNATIVELY SPLICED FN ISOFORMS}

The primary gene transcript of FN is alternatively spliced to generate multiple mRNAs, each encoding a distinct FN subunit. Three sites of alternative splicing lie amongst the type III repeats: extra type III domains EIIIB/ED-B (between $\mathrm{III}_{7}$ and $\mathrm{III}_{8}$ ) and EIIIA/ED-A (between $\mathrm{III}_{11}$ and $\mathrm{III}_{12}$ ), and the variable (V) region/IIICS (between $\mathrm{III}_{14}$ and $\mathrm{III}_{15}$ ) (Hynes 1990; Schwarzbauer 1991a). EIIIA and EIIIB are single type III modules coded for by single exons that are either included or skipped during splicing (Fig. 1). Neither EIIIA nor EIIIB are included in plasma $\mathrm{FN}$, whereas cellular FN monomers can have neither, one, or both of these extra domains. EIIIA and EIIIB modules are highly conserved having identical sequences in virtually all mammals, from humans to the giant panda (JE Schwarzbauer, unpubl.). This conservation contrasts with other type III repeats; for example, the RGD-containing $\mathrm{III}_{10}$ module is identical among primates but diverges in other mammals.

Splicing at the $\mathrm{V}$ region occurs by subdivision of a large exon that encodes the $\mathrm{V}$ region plus the first half of the type $\mathrm{III}_{15}$ module (Schwarzbauer et al. 1983). Alternative $3^{\prime}$ splice sites are used to generate mRNAs encoding three splice variants: V0 which lacks the entire $\mathrm{V}$ region and V95 or V120 which include 95 or 120 amino acids of the $\mathrm{V}$ region, respectively. V0, V95, and V120 are common in mammals but humans have two additional splice variants (V89 and V64) arising from usage of a unique $5^{\prime}$ splice site located 267 bases into the exon (Fig. 1) (Mosher 1989; Hynes 1990). Chickens and frogs differ from mammals and have only two splice variants at the $\mathrm{V}$ region (Norton 1987; DeSimone et al. 1992). In addition, dog cartilage contains a novel splice variant that lacks the $\mathrm{V}$ region, $\mathrm{III}_{15}$ and $\mathrm{I}_{10}$ (MacLeod et al. 1996). Most plasma FN molecules are heterodimers composed of one $\mathrm{V} 0$ and one $\mathrm{V}^{+}$subunit (Hynes 1990). Cellular FN, on the other hand, has very few V0 subunits; most subunits are $\mathrm{V}^{+}$, containing part or all of the $\mathrm{V}$ region.

The exciting finding of FN alternative splicing raised the idea that each of these regions could carry out a unique function. All three sites are positioned to have an effect on cell adhesion. EIIIA and EIIIB flank the RGD/synergy integrin-binding region, whereas EIIIA and the $\mathrm{V}$ region reside on either side of the HepII domain (Fig. 1). In fact, the $\mathrm{V}$ region has a direct role in cell adhesion by binding to $\alpha 4$ integrins through a site in the first 25 amino acids (called CS1) (Wayner et al. 1989; Guan and Hynes 1990; Nojima et al. 1990) and through a secondary CS5 site located 65 residues carboxyterminal to CS1 (Mould et al. 1991). The V region also has effects on the activities of the HepII domain in FN fibrillogenesis (Santas et al. 2002), and it has heparin-binding activity (Mostafavi-Pour et al. 2001) which may allow the $\mathrm{V}$ region to modulate syndecan binding to FN. EIIIA also appears to participate in cell 
adhesion because it binds to $\alpha 4$ and $\alpha 9$ integrins (Liao et al. 2002) and its presence in dimeric FN enhances HT1080 cell attachment (Manabe et al. 1997). Cell binding to EIIIB has not been reported.

The $V$ region has functions other than adhesion. The $\mathrm{V}$ region controls FN dimer secretion such that any V0-V0 dimers that form are retained in the ER and degraded intracellularly (Schwarzbauer et al. 1989). V0- $\mathrm{V}^{+} \mathrm{FN}$ dimers are more efficiently incorporated into fibrin clots than are dimers with two $\mathrm{V}$ regions (Wilson and Schwarzbauer 1992), which may explain, at least partly, the unique subunit composition of plasma $\mathrm{FN} . \mathrm{V}^{+} \mathrm{FN}$ is widely expressed and deposited into the ECM in essentially all tissues (ffrench-Constant and Hynes 1989; Oyama et al. 1989). Interestingly, however, V0-containing dimers are commonly found in tissues because a significant fraction of the $\mathrm{FN}$ in tissues is derived from plasma (Moretti et al. 2007). Some tissue-specific and disease-associated changes in $\mathrm{V}$ region variants have been reported (Oyama et al. 1993; Kumazaki et al. 1999; Schofield and Humphries 1999; Trefzer et al. 2006). Monoclonal antibodies have been generated that show differential reactivity with FN in tumors and developing tissues compared to FN in normal adult tissues. Two of these so-called "oncofetal" epitopes are affected by alternative splicing. One site is recognized only when a certain $\mathrm{Thr}$ residue in the $\mathrm{V}$ region is $\mathrm{O}$-glycosylated (Matsuura et al. 1988). The other site is a cryptic region that becomes exposed with inclusion of EIIIB (Ventura et al. 2010).

In contrast to the prevalence of $\mathrm{V}^{+} \mathrm{FN}$ in most tissues, EIIIA and EIIIB levels are low in adult tissues (Oyama et al. 1989; Pagani et al. 1991), but are up-regulated during development (ffrench-Constant and Hynes 1989; Pagani et al. 1991; Peters et al. 2002), with injury (ffrench-Constant et al. 1989; Kilian et al. 2008), in tumors (Schwarzbauer et al. 1987; Koukoulis et al. 1993; Castellani et al. 1994; Kaczmarek et al. 1994; Astrof and Hynes 2009), and in other diseases (Van Vliet et al. 2001; Kilian et al. 2008). Taken together, the changes in the inclusion of EIIIA and EIIIB suggest that these modules have activities that affect tissue organization and cell-ECM interactions such as might occur in tissue remodeling.

Specific functional roles for EIIIA and EIIIB have not been clearly defined from cell culture experiments. Therefore, generation of null mutations in mice provides a critical test of their requirements. Mice lacking either EIIIA or EIIIB are viable and fertile showing that each individual domain is dispensable for embryogenesis (Fukuda et al. 2002; Muro et al. 2003; Tan et al. 2004). Furthermore, neither is required for neovascularization in mice (Astrof et al. 2004). EIIIA-null mice are reported to have defects in wound repair (Muro et al. 2003) and are less prone to develop atherosclerotic plaques (Tan et al. 2004). Proliferation and FN matrix assembly by cells cultured from EIIIB-null mice were reduced (Fukuda et al. 2002). In contrast to the relatively mild effects in single null mice, double knock out of both EIIIA and EIIIB resulted in embryonic lethality with multiple vascular defects, some of which were specific to the genetic background of the mouse strain (Astrof et al. 2007). Although the defects in mice lacking both EIIIA and EIIIB are severe, mechanistic insights into specific functions for each splice variant in vivo remain to be uncovered.

Alternative splicing appears to contribute to protein solubility and stability. Plasma FN tends to be more soluble than cellular FN at physiological pH (Hynes 1990) and also contains many more $\mathrm{V} 0-\mathrm{V}^{+}$dimers suggesting that the presence or absence of the $\mathrm{V}$ region may affect partitioning of FN between tissue matrices and body fluids. Inclusion of EIIIB makes FN more sensitive to proteolysis (Zardi et al. 1987) suggesting a role in protein stability that might allow more rapid turnover of FN at sites where $\mathrm{EIIIB}^{+} \mathrm{FN}$ levels are high, such as during tissue remodeling where production of extracellular proteases is up-regulated. Thus, circumstantial evidence suggests that, along with any specific functions, alternative splicing might have a general effect on the properties of FN dimers and fibrils by modulating protein solubility and sensitivity to proteolysis. 
Fibronectin Splicing and Assembly

\section{FN FIBRILLOGENESIS: THE STEP-WISE CONVERSION OF FN DIMERS TO FIBRILS}

Multimeric FN fibrils are prevalent in most vertebrate tissues and are the major functional form of FN (Fig. 2). Assembly of FN fibrils is a cellmediated process that depends on binding of FN dimers to integrins (Ali and Hynes 1977; McDonald et al. 1987; Wu et al. 1993). These receptors promote $\mathrm{FN}-\mathrm{FN}$ interactions outside the cell and concomitantly link to the actin cytoskeleton via their cytoplasmic domains. Thus, they coordinate FN fibril architecture with cell shape and intracellular signaling (Wierzbicka-Patynowski and Schwarzbauer 2003; Singh et al. 2010). We have a reasonable understanding of the steps involved in initiation of fibril assembly, but detailed information about the interactions and mechanisms as well as the events that promote fibril maturation into detergent-insoluble matrix remains to be elucidated.

The basic model for FN assembly that has emerged over the past 20-plus years depends on processes that promote cell binding,
FN-FN interactions, and conversion into stable, deoxycholate (DOC) detergent-insoluble matrix fibrils (McKeown-Longo and Mosher 1983; Mao and Schwarzbauer 2005; Singh et al. 2010). FN is secreted as a soluble, covalent dimer (Mosher 1989; Hynes 1990), and the dimer structure is essential for fibrillogenesis (Schwarzbauer 1991b). The dimer has a compact conformation that depends, in part, on long-range interactions between type III modules $\mathrm{III}_{2-3}$ and $\mathrm{III}_{12-14}$ (Johnson et al. 1999). This conformation prevents fibril formation in solution; fibrillogenesis is dependent on FN binding to cells (McDonald 1988). Integrin $\alpha 5 \beta 1$ is the primary receptor for binding to soluble FN (Huveneers et al. 2008) and recognizes the RGD and synergy sites in the $\mathrm{III}_{9-10}$ modules (Pierschbacher and Ruoslahti 1984; Aota et al. 1994). FN binding to $\alpha 5 \beta 1$ induces receptor clustering which brings together bound $\mathrm{FN}$ dimers. Initially, the integrin-bound $\mathrm{FN}$ is in a compact conformation but as assembly progresses, it undergoes conformational changes to become more extended (Baneyx
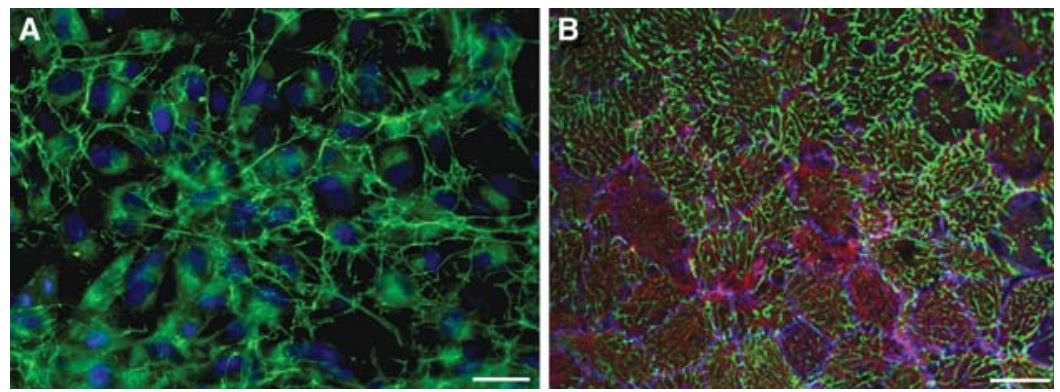

Figure 2. FN matrices in culture and in vivo. (A) Indirect immunofluorescence image shows a typical FN matrix assembled by cells in monolayer culture. Dexamethasone-treated HT1080 fibrosarcoma cells (Brenner et al. 2000) were fixed and permeabilized, and FN was visualized by staining with anti-FN antibodies and fluoresceintagged secondary antibodies. Fibrils (green) extend around and between the cells whose nuclei are visualized by staining DNA with DAPI (blue). Intracellular staining adjacent to the nuclei is most likely FN that is trafficking through the secretory pathway. The organization of fibrils assembled by fibroblast-like cells $(A)$ differs from the fibril arrangements formed by blastocoel roof cells $(B)$ which grow in a multilayered sheet. $(B)$ Indirect immunofluorescence image of the blastocoel roof from a mid-late gastrula stage Xenopus laevis embryo shows native assembly state of the FN matrix at this stage. This is an en face view of the innermost layer of cells in the multicell layered blastocoel roof. These cells face the fluid-filled blastocoel and assemble FN fibrils on their free surfaces. FN fibrils (green) extend across surfaces of cells outlined by C-cadherin staining (blue). Cortical assembly of actin (red) is required for the formation of FN fibrils from pericellular FN that initially assembles at cell-cell boundaries. Note the apparent incomplete progression, or delay, of FN fibril assembly by some cells in the layer. These are cells that have entered the layer as gastrulation proceeds and as a consequence of radial intercalation. Once resident in this layer these cells begin to assemble matrix on their newly "free" surfaces. (Scale bars, $25 \mu \mathrm{m}$.) 
et al. 2001). The FN conformations and interactions within fibrils impart these structures with significant elasticity (Ohashi et al. 1999; Baneyx et al. 2002).

\section{FN-FN Interactions during Fibrillogenesis}

The amino-terminal assembly domain has an essential role in fibrillogenesis as shown by deletion, mutagenesis, and antibody-blocking studies (McDonald et al. 1987; Schwarzbauer 1991b; Sottile et al. 1991). This domain consists of repeats $\mathrm{I}_{1-5}$ within the amino-terminal $70-\mathrm{kDa}$ fragment (Fig. 1) and binds to multiple sites within FN. Two major binding sites for the assembly domain are within the first two type III repeats, one site in native $\mathrm{III}_{2}$ and a second cryptic site that is exposed in denatured III $_{1}$ (Aguirre et al. 1994; Hocking et al. 1994). The $\mathrm{III}_{1-2}$ domain has a unique structure compared to other pairs of type III modules in that it has an extra-long linker that may facilitate folding to regulate FN interactions (Leahy et al. 1996; Vakonakis et al. 2007). Results from a variety of approaches support the conclusion that conformational changes in the $\mathrm{III}_{1-2}$ domain are involved in FN binding to this region. Mechanical stretching of $\mathrm{FN}$ enhances binding of $70 \mathrm{kDa}$ (Zhong et al. 1998). Changes in the fluorescence resonance energy transfer (FRET) signal from a CFP-III ${ }_{1-2}$-YFP FRET sensor protein were detected on binding of $70 \mathrm{kDa}$ (Karuri et al. 2009). Complementary mutations that eliminate a salt-bridge interaction between III $_{1}$ and $\mathrm{III}_{2}$ increase binding of $70 \mathrm{kDa}$ (Karuri et al. 2009). A key role for III $_{1-2}$ in fibril formation is shown by blockade of assembly by antibodies to III $_{1-2}$ (Chernousov et al. 1987, 1991), and by deletion of $\mathrm{III}_{1-2}$ from recombinant FN (Sechler et al. 2001). Furthermore, anastellin, a FN fragment containing part of $\mathrm{III}_{1}$, binds to $\mathrm{FN}$ at multiple sites in $\mathrm{III}_{1-3}$ (Ohashi and Erickson 2005) and induces formation of fibrous FN aggregates that are DOC-insoluble (Morla et al. 1994). These results lead to the conclusion that $\mathrm{III}_{1-2}$ plays a critical role in FN assembly and may be essential for conversion of fibrils into a DOC-insoluble form (Morla and Ruoslahti 1992; Sechler et al. 2001).
The 70-kDa fragment binds to other sites in FN including the HepII domain and a cryptic site in III $_{4-5}$ (Bultmann et al. 1998; Maqueda et al.2007). Current evidence suggests that these interactions are not essential for fibrillogenesis, so what might be the roles of these sites? One possibility is that FN-FN interactions at multiple sites might be needed to shift the assembly reaction toward fibrillogenesis by reducing the rate of dissociation of interacting $\mathrm{FN}$ dimers. Another possibility is that fibril strength and stability may be enhanced by interactions along the length of the FN subunits, and this could reduce fibril breakage in response to the application of force (Engler et al. 2009). If fibrillogenesis works, in part, like a zipper, then a third possibility is that multiple interacting sites may act like zipper teeth with the alignment of FN molecules determined by the initial interaction. Finally, it is possible that the cryptic sites may become exposed only after FN is within a fibril which might position them to initiate fibril branching (Singh et al. 2010). All of these potential mechanisms for fibril formation and function remain to be tested.

\section{FN Receptor Requirements and Intracellular Connections}

FN binding to integrins promotes formation of adhesion complexes where integrin cytoplasmic tails make connections with the actin cytoskeleton (Dubash et al. 2009). The continuity of interactions from FN through integrins to actin stress fibers is critical for matrix assembly. Stress fibers, which are contractile actin-myosin filaments, generate tension at sites of contact between integrins and FN. $\alpha 5 \beta 1$ integrin engagement with the cytoskeleton allows these receptors to translocate away from these contact sites along actin filaments (Pankov et al. 2000) and, in the process, to pull on bound FN molecules and promote fibrillogenesis (Pankov et al. 2000; Ohashi et al. 2002). Treatments that stimulate cell contractility are known to induce conformational changes that expose FN binding sites (Zhong et al. 1998) and to enhance incorporation of FN into fibrils (Zhang et al. 1994). Although $\alpha 5 \beta 1$ integrin is primarily responsible 
for FN matrix assembly, other integrins can form FN fibrils but appropriate stimulation, such as with $\mathrm{Mn}^{2+}$ or with activating antiintegrin antibodies, is usually required in vitro. These other integrins include $\alpha 4 \beta 1$ (Sechler et al. 2000), $\alpha v \beta 1$ (Zhang et al. 1993; Yang and Hynes 1996), $\alpha v \beta 3$ (Wennerberg et al. 1996; Wu et al. 1996; Takahashi et al. 2007), and $\alpha \mathrm{IIb} \beta 3$ (Olorundare et al. 2001). Syndecan-1 and syndecan-2 also participate in FN assembly (Klass et al. 2000; Galante and Schwarzbauer 2007; Stepp et al. 2010).

Focal adhesion kinase (FAK) is activated by integrin binding to FN. Its activation is essential for matrix assembly in vitro, and matrix is significantly diminished in FAK-null embryos (Ilic et al. 2004). Many other signaling molecules are activated by integrin binding to $\mathrm{FN}$, but inhibition or knockdown of these molecules, including Src, paxillin, PI-3-kinase, and protein kinase $\mathrm{C}$, delays but does not eliminate fibrillogenesis (Somers and Mosher 1993; Wierzbicka-Patynowski and Schwarzbauer 2002; Wierzbicka-Patynowski et al. 2007). There appear to be parallel or overlapping sets of signaling pathways that can support matrix assembly and, if one pathway is blocked, other downstream molecules can be recruited to take their place.

One key molecule in regulating assembly is Rho GTPase. Activation of Rho GTPase and downstream Rho kinase stimulates cell contractility (Yoneda et al. 2005; Dubash et al. 2009) and plays a critical role in fibrillogenesis (Zhang et al. 1994; Zhong et al. 1998; Yoneda et al. 2007). Modulation of Rho activity affects the incorporation of FN into matrix fibrils and changes matrix reactivity with certain antibodies (Zhang et al. 1994; Zhong et al. 1998; Smith et al. 2007). Importantly, Rho action exposes binding sites required for FN-FN interactions (Zhong et al 1998). In fact, contractility promotes integrin engagement of FN's synergy site and thus increases $\alpha 5 \beta 1-\mathrm{FN}$ bond strength (Friedland et al. 2009); this effect on bond strength could explain why the synergy site is required for matrix assembly (Nagai et al. 1991; Sechler et al. 1997). Fibrils within a matrix are under significant tension and relax to as little as one-quarter of their original length when tension is removed, for example, when one end of a fibril is released from its attachment site (Ohashi et al. 1999). Thus, cell contractility and tension are needed to initiate fibrillogenesis and to maintain fibril architecture in established matrices.

\section{Fibrillogenesis and Conversion to DOC Insolubility}

Initiation of assembly depends on FN binding to integrins and subsequent conformational changes in bound FN. These events lead to interactions between FN dimers to form multimers and short fibrils that are soluble in DOC detergent (Choi and Hynes 1979; McKeownLongo and Mosher 1983). FN dimers associate end-to-end (Dzamba and Peters 1991), and continued deposition then serves to lengthen and thicken the fibrils. With time, FN fibrils are irreversibly converted from DOC-soluble into DOC-insoluble matrix (Choi and Hynes 1979; McKeown-Longo and Mosher 1983). Fibril insolubility appears to depend on strong noncovalent, protein-protein interactions (Chen and Mosher 1996; Ohashi and Erickson 2009) and is likely to involve $\beta$-strand exchange interactions as have been observed in the formation of amyloid-like fibrils in a solution of partially denatured $\mathrm{III}_{9}$ modules (Litvinovich et al. 1998). Insoluble FN matrix may form through a dock-and-lock mechanism (Esler et al. 2000) in which FN dimers first associate reversibly with fibrils and then undergo conformational changes to become irreversibly incorporated into fibrils. Recombinant FN with $\mathrm{III}_{1-2}$ deleted (FN $\left.\Delta \mathrm{III}_{1-2}\right)$ was severely deficient in conversion into DOC-insoluble material (Sechler et al. 2001) which suggests that this domain may participate in forming strong protein interactions. However, strong interactions involving other domains are possible because a recombinant FN that lacks a larger region $\left(\mathrm{FN} \Delta \mathrm{III}_{1-7}\right)$ forms DOC-insoluble matrix at a more rapid rate than wild type FN (Sechler et al. 1996).

FN fibrillogenesis and formation of DOC-insoluble matrix influence the onset and 
progression of certain diseases. For example, mutations in FN have been linked to the hereditary kidney disease glomerulopathy with fibronectin deposits (GFND) (Castelletti et al. 2008) characterized by granular deposits of FN aggregates (Strøm et al. 1995). Two of the mutations associated with this disease are in $\mathrm{FN}$ repeat $\mathrm{III}_{13}$ and cause a reduction in heparin-binding activity. These mutations may also affect syndecan binding to the HepII domain. Because syndecan-2 is required for FN matrix assembly (Klass et al. 2000; Galante and Schwarzbauer 2007), this disease may progress through loss of syndecan-FN interactions resulting in disorganized fibrils. Clearly, much more research is needed about how FN matrix becomes insoluble and how dysregulation of this step contributes to diseases and scarring.

\section{FN FIBRILLOGENESIS: DEVELOPMENTAL MECHANISMS AND CONSEQUENCES OF ASSEMBLY}

FN was a primary early focus of analyses of ECM functions in embryogenesis and it has been implicated in many fundamental developmental processes (Dzamba et al. 2001; Astrof and Hynes 2009; Rozario and DeSimone 2010). Unlike many other ECM proteins including the collagens and laminins, FN appears to be a chordate innovation. FN-like genes have yet to be identified for any protostome (Hynes and Zhao 2000; Rubin et al. 2000) or nonchordate deuterostome (Whittaker et al. 2006; Tucker and Chiquet-Ehrismann 2009). Thus, it has been suggested that FN and other proteins such as von Willebrand factor and the tenascins may have first arisen along with the blood vasculature and/or neural crest of the vertebrates (Hynes and Zhao 2000; Whittaker et al. 2006). Whether or not the origins of these tissues are linked to the emergence of the FN protein, it is clear that $\mathrm{FN}$ is an indispensable component of vertebrate ECMs involved in a wide range of developmental events.

FN is expressed early in vertebrate embryogenesis, and initial studies of both avian (Critchley et al. 1979; Duband and Thiery
1982; Sanders 1982) and amphibian embryos (Boucaut and Darribere 1983a,b; Lee et al. 1984) revealed that $\mathrm{FN}$ is assembled prior to the initiation of gastrulation movements. During gastrulation, an elaborate network of FN is detected predominantly at the basal surfaces of the endoderm and ectoderm in the chick (Krotoski et al. 1986) and along the blastocoel roof in amphibians (Lee et al. 1984) consistent with the role of the FN matrix as a migratory substrate for the mesoderm. The importance of FN to mesoderm migration was subsequently confirmed using blocking antibodies and RGD-containing peptides in both systems (Boucaut et al. 1984a,b; Brown and Sanders 1991; Winklbauer et al. 1996). FN and other ECM proteins including laminins and tenascin have also been suggested to provide guidance cues for many other cells and tissues including primordial germ cells in frogs (Heasman et al. 1981) and mice (ffrench-Constant et al. 1991), and avian neural crest (Duband and Thiery 1982; Rovasio et al. 1983; Boucaut et al. 1984). Targeted disruption of the FN gene in mice is embryonic lethal, and these embryos display severe defects in mesoderm development affecting notochord and somite formation, and normal development of the heart and vasculature (George et al. 1993; Georges-Labouesse et al. 1996). Morpholino knockdowns of FN in zebrafish are also characterized by failures of mesoderm migration and somite boundary formation (Jülich et al. 2005; Latimer and Jessen 2010). In the zebrafish natter mutant, which lacks one of the two FN genes expressed in this species, defects in heart tube formation are observed and attributable to failures in organization of the myocardial epithelium but not myocardial cell migration per se, even though initiation of cell movement does appear to require deposition of FN specifically at the midline (Trinh and Stainier 2004). Clearly, these and other studies of FN and its many roles in embryonic development point to the importance not only of proper regulation of FN expression but also the localized assembly of FN-containing ECM at the right "times and places" to promote normal morphogenesis and differentiation. 
Importance of FN Fibrillogenesis and Assembly States

How ECM is assembled at cell and tissue surfaces has become an increasingly important question in large part because of a growing realization that the three-dimensional (3D) organization of the ECM can have distinct instructive properties in terms of cellular responses. FN, along with other ECM glycoproteins, collagens, and proteoglycans, are assembled into complex $3 \mathrm{D}$ microenvironments that provide structural support to cells and tissues, and restrict the diffusion of growth factors and other soluble signaling molecules to direct or influence cell behavior, proliferation and growth, gene expression, and cell fate specification (Rozario and DeSimone 2010). The physical and mechanical properties of the ECM and corresponding mechanisms of rigidity-sensing used by cells in contact with it also play important roles in these processes (McBeath et al. 2004; Paszek et al. 2005; Engler et al. 2006). During embryogenesis, matrix assembly is initiated and assembled matrices are subsequently remodeled as development proceeds. This raises the interesting possibility that progressive changes in assembly state can serve to regulate cell behaviors, possibly by acting as a developmental "checkpoint" for subsequent morphogenetic and/or cell-fate decisions.

Regulated FN deposition is essential for cleft formation during epithelial branching morphogenesis with both localized synthesis and transient assembly of FN observed at sites of forming clefts (Sakai et al. 2003). Inhibition of FN assembly or knock-down of FN synthesis blocks cleft formation and branching, whereas the addition of exogenous FN promotes these processes. Interestingly, the assembly of $\mathrm{FN}$ at sites of cleft formation was associated with a reduction in cadherin-dependent cell-cell adhesions suggesting a possible mechanistic link or adhesive "crosstalk" critical for branching morphogenesis to proceed (Sakai et al. 2003). Onodera et al. (2010) recently identified the Btbd7 gene as a key regulator of branching in this system. Btbd7 is expressed by cells in the emerging clefts in response to local FN accumulation. Btbd7 induces Snail2 and suppresses E-cadherin expression thereby promoting morphogenetic changes required for cleft formation.

Methods used to block or disrupt the normal deposition and assembly of FN fibrils in embryos have included injection of RGD peptides, antibodies directed against $\beta 1$ integrins (Darribere et al. 1990) or FN (Marsden and DeSimone 2001), and the expression of integrin $\beta 1$ dominant-negative constructs (Marsden and DeSimone 2003). However, these manipulations effectively block initial FN binding to cell surfaces. Thus, any contributions of intermediate states of assembly to a given developmental process are not readily resolvable using such reagents. Darribere and Schwarzbauer (2000) injected recombinant forms of FN into amphibian blastula-stage embryos that coassembled with endogenous FN and formed disorganized chimeric matrices. Gastrulation movements were perturbed in these embryos highlighting the importance of ECM architecture in directing normal cell behaviors. Nakatsuji and Johnson (Nakatsuji et al. 1982; Nakatsuji and Johnson 1984) have proposed that the physical orientation of assembled FN fibrils along the blastocoel roof is critical for directed cell migration of the mesendoderm; however, it remains unclear whether contact guidance is an intrinsic property of the fibrillar network laid down in vivo. Nevertheless, there is ample evidence that FN fibrils are critical for normal mesendodermal protrusive behaviors (Winklbauer and Keller 1996; Winklbauer et al. 1996; Nagel and Winklbauer 1999) possibly through a chemotactic mechanism involving the sequestration of PDGF by assembled fibrils (Nagel et al. 2004). Although artificial substrates conditioned with the fibrillar matrix of the blastocoel roof clearly support the directional migration of mesendodermal cells and explants in vitro (Nakatsuji and Johnson 1983, 1984; Shi et al. 1987; Winklbauer et al. 1992), mesendoderm will still move directionally toward the animal pole in the presence of nonfibrillar FN if the normal circular geometry of the tissue is maintained (Davidson et al. 2002; Rozario et al. 2009). 
More recently, a $70-\mathrm{kDa}$ amino-terminal fragment of FN known to block FN fibril assembly (Fig. 1) (McKeown-Longo and Mosher 1985; McDonald et al. 1987) was used to prevent the nascent pericellular FN matrix that first accumulates along the blastocoel roofs of blastula and early gastrula-stage Xenopus embryos (Fig. 2) from forming fibrils (Rozario et al. 2009). FN fibrillogenesis normally proceeds in this system coincident in space and time (Davidson et al. 2004, 2008) with the three major morphogenetic movements that drive gastrulation (radial intercalation and epiboly, mediolateral intercalation and convergent extension, and mesendoderm migration), each of which has been shown to require FN (Winklbauer and Keller 1996; Marsden and DeSimone 2001, 2003; Davidson et al. 2002, 2006). Inhibition of FN fibril assembly but not FN binding to cell surfaces has no apparent effect on axis elongation indicating that convergent extension is largely unaffected in the absence of FN fibrils. In contrast, radial intercalation of blastocoel roof cells is perturbed when FN fibrillogenesis is blocked, resulting in a failure of epibolic spreading and thinning of the blastocoel roof (Rozario et al 2009). Randomization of the normally parallel alignment of mitotic spindles in dividing roof cells also occurs in the absence of FN fibrils and this likely contributes to the failure of these cells to intercalate properly; polarized cell division was shown previously to be required for normal morphogenetic movements in Xenopus gastrulae (Marsden and DeSimone 2001) and in other systems (Wei and Mikawa 2000; Gong et al. 2004). Finally, the velocity of mesendoderm cell migration along the blastocoel roof is increased in embryos lacking fibrils (Rozario et al 2009) suggesting that the fibrillar FN substrate normally slows the migration of these cells, possibly because of differences in adhesive strength (Palecek et al. 1997) or integrin clustering (Guo et al. 2002). In normal embryos, the migrating mesendoderm remodels and reduces the apparent density of fibrillar FNs assembled by the blastocoel-roof cells as they pass over it (Davidson et al. 2004).

Together, these observations provide compelling support for the hypothesis that at least some developmental events are regulated by the physical assembly state and 3D architecture of FN-rich ECMs. Thus, how FN assembly and remodeling are spatio-temporally controlled in vivo becomes critical to our understanding of morphogenetic mechanisms and possibly the regulation of gene expression, cell fate, and proliferation. It remains to be established to what extent cellular responses to progressive changes in FN assembly state in embryos reflect actual differences in FN conformation (e.g., exposure of cryptic binding sites) and density (e.g., haptotaxis, number of cell-binding sites), and/or the overall mechanical properties (e.g., stiffness, $3 \mathrm{D}$ organization) and composition of the assembled matrix (e.g., binding of other matrix molecules, growth factors and cytokines).

Unlike the situation with $2 \mathrm{D}$ or even $3 \mathrm{D}$ cellculture models, FN matrix assembly in embryos frequently proceeds coincident with highly dynamic cell movements and tissue rearrangements. During primitive streak formation in the chick, dramatic displacements of FN and fibrillin are observed in register with epiblastic cell movements (Czirok et al. 2006; Zamir et al. 2006). Similar correlations between FN assembly, remodeling, and cell movements are also apparent in frog embryos undergoing convergence and extension movements (Davidson et al. 2008). These observations highlight the importance of considering not only the biomechanical context in which fibril assembly initiates but also the likely functional roles of a FN matrix that translocates along with cells and tissues during morphogenesis. These studies underscore our limited understanding of dynamic cell-ECM interactions particularly as they relate to forces generated by the cells and tissues that drive morphogenesis in vivo.

\section{How Is FN Matrix Assembly Initiated in Embryos?}

As we have discussed, much is now known about mechanisms of FN matrix assembly based on studies of mammalian cells in culture (Singh et al. 2010). A key feature of current models of this process involves the generation of cell tension through integrins on stiff substrates 
(Halliday and Tomasek 1995; Zhang et al. 1997; Zhong et al. 1998; Pankov et al. 2000) but how FN assembly initiates in vivo on the free surfaces of multicell-layered tissues is less clear. The initial assembly of FN in Xenopus embryos serves as a useful example of this problem. A pericellular nonfibrillar FN matrix first begins to assemble at the free surfaces of cells in the multilayered blastocoel roof that face the blastocoel cavity, which is a fluid-filled space rich in soluble FN (Lee et al. 1984). FN "puncta" assembled at cell surfaces give way to an elaborate fibrillar matrix that crosses cell boundaries, and becomes thicker over time (Fig. 2). Assembly and remodeling are surprisingly dynamic and complex with individual fibrils forming and breaking connections with one another, undergoing rapid recoil and displaying considerable movement relative to the cells on which they form (Davidson et al. 2008). Although the question of how FN assembly is initiated in this system has been of interest to developmental biologists for many years, no obvious differences in FN or integrin $\alpha 5 \beta 1$ expression have been reported that could account for the tight spatio-temporal regulation of assembly; all cells in the embryo express the integrin and FN is secreted into the blastocoel at concentrations sufficient to allow assembly well before assembly begins (Lee et al. 1984; Joos et al. 1995; Winklbauer 1998). In contrast, some of the first clues to emerge suggested that cellcell adhesion and tissue tension may instead play a critical role in regulating FN assembly (Winklbauer 1998; Dzamba et al. 2009).

During the period in which FN assembly begins, blastocoel-roof cells change shape from round to polygonal (Dzamba et al. 2009), indicating that cell-cell adhesion and tension have increased (Lecuit and Lenne 2007). Moreover, experimentally applied mechanical deformations designed to increase or decrease tension in the blastocoel roof promoted or blocked FN fibril assembly, respectively (Dzamba et al. 2009). Overexpression of cadherins in blastocoel-roof cells also resulted in a precocious change in cell shape and early initiation of FN fibril assembly, whereas inhibition of cadherin adhesion blocked fibril formation (Dzamba et al. 2009).
C-cadherin mediated adhesion is normally greater in the blastocoel roof than in other parts of the embryo at these stages (Reintsch and Hausen 2001) and, whereas changes in C-cadherin adhesion are known to occur during gastrulation, this does not appear to be the result of alterations in C-cadherin levels at the cell surface (Brieher and Gumbiner 1994). So, how might cadherin adhesion normally be regulated in cells of the blastocoel roof, and can regional changes in cell adhesion regulate $\mathrm{FN}$ matrix assembly, an integrin-dependent process?

To address these issues, Dzamba et al. (2009) began by investigating the role of the noncanonical Wnt/PCP (planar cell polarity) signaling pathway in FN matrix assembly. Inhibition of Wnt/PCP signaling with a dominant-negative Wnt11 construct prevented FN fibril assembly, which could in turn be rescued by expressing constitutively active forms of Rac or Rho. Surprisingly, reduced Wnt/PCP signaling had little effect on the ability of these cells to apply traction stresses to artificial FN substrates whereas average traction stresses were reduced on Ccadherin-FC substrates under these same conditions (Dzamba et al. 2009). This result is consistent, however, with previous studies in the zebrafish in which disruptions in Wnt/ PCP signaling were correlated with reduced cadherin adhesion and tissue cohesivity (Ulrich et al. 2005). Based on these data, a model for FN fibril assembly in tissues was proposed in which cadherin-dependent changes in cell-cell adhesion result in a reorganization of the cortical actin cytoskeleton (Dzamba et al. 2009). A Rac- and Pak-dependent contractile event is then required for translocation of integrins with bound FN from sites of cell-cell contact where the pericellular matrix first forms. Thus, nascent cell-cell adherens-like junctions in this early embryonic tissue perform an analogous function to focal adhesions in vitro by generating the tension on integrins necessary to expose cryptic sites within FN that are required for self-association and fibril formation. It will be of considerable interest in the future to establish whether a similar mechanism(s) is widely used by other tissues in vivo to regulate $\mathrm{FN}$ matrix assembly. 
Both FN (Marsden and DeSimone 2001; Davidson et al. 2006; Latimer and Jessen 2010) and the Wnt/PCP pathway (Heisenberg et al. 2000; Wallingford et al. 2000) are required for convergent extension movements in Xenopus and the zebrafish. FN alone is insufficient to rescue convergent extension defects in the absence of Wnt/PCP signals (Davidson et al. 2006). These observations suggest that one important function of the Wnt/PCP pathway in embryogenesis is the regulation of FN matrix assembly, which in turn is required for subsequent morphogenetic movements. However, whereas FN is clearly required for the protrusive activity that drives convergence and extension movements (Davidson et al. 2006), Wnt/PCP signals are essential for directed cell polarity. Other mechanisms have also been reported to contribute to matrix assembly in embryos. For example, syndecan-1 and -2 promote FN matrix assembly at gastrulation in Xenopus (Kramer and Yost 2002). A connection to syndecans may extend beyond just matrix assembly because it has also been reported that syndecan- 4 regulates $\mathrm{Wnt} / \mathrm{PCP}$ signaling and is required for normal convergence and extension movements. In this instance, $\mathrm{FN}$ is proposed to act in concert with syndecan-4 to activate Wnt/PCP signaling (Muñoz et al. 2006). Other cell-signaling pathways have been implicated in the regulation of matrix assembly in development. For example, FAK and Ena/Vasp are required for FN assembly at intersomitic boundaries in Xenopus (Kragtorp and Miller 2006). In addition, Jülich et al. (2009) reported that Eph/Ephrin signaling is required for integrin $\alpha 5 \beta 1$ clustering at emergent somite borders in the zebrafish resulting in localized assembly of the FN matrix. The requirement for fibronectin and integrin $\alpha 5 \beta 1$ in somitogenesis is conserved among multiple vertebrate species including frog (Kragtorp and Miller 2007) and mouse (Yang et al. 1993; Yang and Hynes 1996). The overall conclusion from these studies is that FN matrix assembly is a complex process that is tightly regulated in vivo and throughout embryogenesis. A key challenge remains the identification of mechanisms of cell adhesion, signaling, and force generation that combine to establish the proper spatio-temporal control of FN deposition.

\section{CONCLUSIONS AND PERSPECTIVES}

The integration of work from many labs has provided mechanistic insights into how soluble dimeric FN is converted into insoluble multimeric fibrils and a rudimentary understanding of the functions of multiple alternatively spliced $\mathrm{FN}$ isoforms. Matrix assembly requires $\mathrm{FN}$, integrins, and molecules that connect integrins to the cytoskeleton. On the FN side of the plasma membrane, direct interactions with receptors combined with temporally and spatially regulated exposure of FN self-association sites orchestrate fibril formation. At the membrane, integrin clustering provides tethering sites to initiate fibrillogenesis. Inside the cell, integrin connections to the cytoskeleton align actin filaments with extracellular fibrils. Information is exchanged between inside and out through activation of specific signaling molecules (e.g., FAK and Rho), through integrin translocation, which applies tension and may induce essential conformational changes, and through crosstalk with cadherins at cell-cell contacts in intact tissues.

This sketch of the assembly process covers the major events but many mechanistic questions remain to be solved. For example, our understanding of how FN dimers are organized within a multimeric fibril is limited. Are there specific FN domains that interact to initiate fibrillogenesis or is initiation a stochastic process? Is the organization of molecules in a fibril dependent on a specific spatiotemporal process that links tension, integrin translocation, and FN conformational changes? Are FN molecules oriented within fibrils to present certain binding sites on the fibril surface? During fibril growth, are $\mathrm{FN}$ dimers added at the ends, laterally, or both? To address these and other questions will require new or enhanced microscopic and biochemical methods for dissecting multicomponent complexes in situ.

Innumerable studies using cultured cells to define and dissect specific steps in FN fibrillogenesis have laid the groundwork. However, 
stationary cells in culture may represent a specialized case of assembly because, in vivo, matrix assembly often occurs during periods of cell movement and morphogenesis. Moreover, studies in vivo and with $3 \mathrm{D}$ substrates in vitro show that the cellular microenvironment affects matrix assembly. A deeper understanding of the mechanisms of matrix assembly, the generation of tension, the potential roles for other ECM proteins, and fibril contributions to matrix stiffness and cell traction must take into account dynamic cellular behaviors and the biomechanics involved in promoting (or limiting) assembly.

\section{ACKNOWLEDGMENTS}

The authors acknowledge support from the NIH (CA44627 and GM59383 to J.E.S.; HD26402 and GM094793 to D.W.D.). We thank Cara Carraher and Bette Dzamba for critical reading of the manuscript. We also thank Bette Dzamba for contributing the immunofluorescence image of Xenopus blastocoel roof cells and Dan Slone for immunofluorescence of HT1080 cell FN matrix.

\section{REFERENCES}

Aguirre KM, McCormick RJ, Schwarzbauer JE. 1994. Fibronectin self-association is mediated by complementary sites within the amino-terminal one-third of the molecule. J Biol Chem 269: 27863-27868.

Ali IU, Hynes RO. 1977. Effects of cytochalasin B and colchicine on attachment of a major surface protein of fibroblasts. Biochim Biophys Acta 471: 16-24.

Aota S, Nomizu M, Yamada K. 1994. The short amino acid sequence pro-his-ser-arg-asn in human fibronectin enhances cell adhesive function. J Biol Chem 269: 24756-24761.

Astrof S, Hynes RO. 2009. Fibronectins in vascular morphogenesis. Angiogenesis 12: 165-175.

Astrof S, Crowley D, Hynes RO. 2007. Multiple cardiovascular defects caused by the absence of alternatively spliced segments of fibronectin. Dev Biol 311: 11-24.

Astrof S, Crowley D, George EL, Fukuda T, Sekiguchi K, Hanahan D, Hynes RO. 2004. Direct test of potential roles of EIIIA and EIIIB alternatively spliced segments of fibronectin in physiological and tumor angiogenesis. Mol Cell Biol 24: 8662-8670.

Baneyx G, Baugh L, Vogel V. 2001. Coexisting conformations of fibronectin in cell culture imaged using fluorescence resonance energy transfer. Proc Natl Acad Sci 98: 14464-14468.
Baneyx G, Baugh L, Vogel V. 2002. Fibronectin extension and unfolding within cell matrix fibrils controlled by cytoskeletal tension. Proc Natl Acad Sci 99: 5139-5143.

Barkalow FJ, Schwarzbauer JE. 1994. Interactions between fibronectin and chondroitin sulfate are modulated by molecular context. J Biol Chem 269: 3957-3962.

Bork P, Doolittle RF. 1992. Proposed acquisition of an animal protein domain by bacteria. Proc Natl Acad Sci 89: 8990-8994.

Boucaut JC, Darribere T. 1983a. Fibronectin in early amphibian embryos. Migrating mesodermal cells contact fibronectin established prior to gastrulation. Cell Tissue Res 234: 135-145.

Boucaut JC, Darribere T. 1983b. Presence of fibronectin during early embryogenesis in amphibian Pleurodeles waltlii. Cell Differ 12: 77-83.

Boucaut J-C, Darribere T, Poole TJ, Aoyama H, Yamada KM, Thiery JP. 1984a. Biologically active synthetic peptides as probes of embryonic development: A competitive peptide inhibitor of fibronectin function inhibits gastrulation in amphibian embryos and neural crest cell migration in avian embryos. J Cell Biol 99: 1822-1830.

Boucaut JC, Darribère T, Boulekbache H, Thiery JP. 1984b. Prevention of gastrulation but not neurulation by antibodies to fibronectin in amphibian embryos. Nature 307: 364-367.

Boucaut JC, Darribère T, Poole TJ, Aoyama H, Yamada KM, Thiery JP. 1984c. Biologically active synthetic peptides as probes of embryonic development: A competitive peptide inhibitor of fibronectin function inhibits gastrulation in amphibian embryos and neural crest cell migration in avian embryos. J Cell Biol 99: 1822-1830.

Bowditch RD, Hariharan M, Tominna EF, Smith JW, Yamada KM, Getzoff E, Ginsberg M. 1994. Identification of a novel integrin binding site in fibronectin: Differential utilization by $\beta 3$ integrins. J Biol Chem 269: 10856-10863.

Brenner KA, Corbett SA, Schwarzbauer JE. 2000. Regulation of fibronectin matrix assembly by activated Ras in transformed cells. Oncogene 19: 3156-3163.

Brieher WM, Gumbiner BM. 1994. Regulation of Ccadherin function during activin induced morphogenesis of Xenopus animal caps. J Cell Biol 126: 519-527.

Brown AJ, Sanders EJ. 1991. Interactions between mesoderm cells and the extracellular matrix following gastrulation in the chick embryo. J Cell Sci 99: 431-441.

Bultmann H, Santas AJ, Pesciotta Peters DM. 1998. Fibronectin fibrillogenesis involves the heparin II binding domain of fibronectin. J Biol Chem 273: 2601-2609.

Castelletti F, Donadelli R, Banteria F, Hildebrandt F, Zipfel PF, Bresin E, Otto E, Skerka C, Renieri A, Todeschini M, et al. 2008. Mutations in FN1 cause glomerulopathy with fibronectin deposits. Proc Natl Acad Sci 105: 2538-2543.

Castellani P, Viale G, Dorcaratto A, Nicolo G, Kaczmarek J, Querze G, Zardi L. 1994. The fibronectin isoform containing the ED-B oncofetal domain: A marker of angiogenesis. Int J Cancer 59: 612-618.

Chen H, Mosher DF. 1996. Formation of sodium dodecyl sulfate-stable fibronectin multimers. J Biol Chem 271: 9084-9089. 
J.E. Schwarzbauer and D.W. DeSimone

Chernousov MA, Fogerty FJ, Koteliansky VE, Mosher DF. 1991. Role of the I-9 and III-1 modules of fibronectin in the formation of an extracellular fibronectin matrix. J Biol Chem 266: 10851-10858.

Chernousov MA, Faerman AI, Frid MG, Printseva OY, Koteliansky VE. 1987. Monoclonal antibody to fibronectin which inhibits extracellular matrix assembly. FEBS Lett 217: 124-128.

Choi MG, Hynes RO. 1979. Biosynthesis and processing of fibronectin in NIL.8 hamster cells. J Biol Chem 254: 12050-12055.

Corbett SA, Lee L, Wilson CL, Schwarzbauer JE. 1997. Covalent cross-linking of fibronectin to fibrin is required for maximal cell adhesion to a fibronectin-fibrin matrix. J Biol Chem 272: 24999-5005.

Couchman JR. 2010. Transmembrane signaling proteoglycans. Annu Rev Cell Dev Biol 26: 89-114.

Critchley DR, England MA, Wakely J, Hynes RO. 1979. Distribution of fibronectin in the ectoderm of gastrulating chick embryos. Nature 280: 498-500.

Czirok A, Zamir EA, Filla MB, Little CD, Rongish BJ. 2006. Extracellular matrix macroassembly dynamics in early vertebrate embryos. Curr Top Dev Biol 73: 237-258.

Darribere T, Schwarzbauer JE. 2000. Fibronectin matrix composition and organization can regulate cell migration during amphibian development. Mech Dev 92: 239-250.

Darribere T, Guida K, Larjava H, Johnson KE, Yamada KM, Thiery JP, Boucaut JC. 1990. In vivo analysis of integrin b1 subunit function in fibronectin matrix assembly. J Cell Biol 110: 1813-1823.

Davidson LA, Keller R, DeSimone DW. 2004. Assembly and remodeling of the fibrillar fibronectin extracellular matrix during gastrulation and neurulation in Xenopus laevis. Dev Dyn 231: 888-895.

Davidson L, Dzamba B, Keller R, Desimone D. 2008. Live imaging of cell protrusive activity, and extracellular matrix assembly and remodeling during morphogenesis in the frog, Xenopus laevis. Dev Dyn 237: 2684-2692.

Davidson LA, Hoffstrom BG, Keller R, DeSimone DW. 2002. Mesendoderm extension and mantle closure in Xenopus laevis gastrulation: Combined roles for integrin $\alpha_{5} \beta_{1}$, fibronectin, and tissue geometry. Dev Biol 242: 109-129.

Davidson LA, Marsden M, Keller R, DeSimone DW. 2006. Integrin $\alpha_{5} \beta_{1}$ and fibronectin regulate polarized cell protrusions required for Xenopus convergence and extension. Curr Biol 16: 833-844.

DeSimone DW, Norton PA, Hynes RO. 1992. Identification and characterization of alternatively spliced fibronectin mRNAs expressed in early Xenopus embryos. Dev Biol 149: 357-369.

Duband JL, Thiery JP. 1982. Distribution of fibronectin in the early phase of avian cephalic neural crest cell migration. Dev Biol 93: 308-323.

Dubash AD, Menold MM, Samson T, Boulter E, GarcíaMata R, Doughman R, Burridge K. 2009. Chapter 1. Focal adhesions: New angles on an old structure. Int Rev Cell Mol Biol 277: 1-65.

Dzamba BJ, Peters DM. 1991. Arrangement of cellular fibronectin in noncollagenous fibrils in human fibroblast cultures. J Cell Sci 100: 605-612.
Dzamba BJ, Bolton MA, DeSimone DW. 2001. The integrin family of cell adhesion molecules. In Cell adhesion (ed. Beckerle MC), pp. 100-154. Oxford University Press, Oxford.

Dzamba BJ, Jakab KR, Marsden M, Schwartz MA, DeSimone DW. 2009. Cadherin adhesion, tissue tension, and noncanonical Wnt signaling regulate fibronectin matrix organization. Dev Cell 16: 421-432.

Edsall JT. 1978. Some early history of cold-insoluble globulin. Ann N Y Acad Sci 312: 1-10.

Engler AJ, Chan M, Boettiger D, Schwarzbauer JE. 2009. A novel mode of cell detachment from fibrillar fibronectin matrix under shear. J Cell Sci 122: 1647-1653.

Engler AJ, Sen S, Sweeney HL, Discher DE. 2006. Matrix elasticity directs stem cell lineage specification. Cell 126: 677-689.

Esler WP, Stimson ER, Jennings JM, Vinters HV, Ghilardi JR, Lee JP, Mantyh PW, Maggio JE. 2000. Alzheimer’s disease amyloid propagation by a template-dependent dock-lock mechanism. Biochemistry 39: 6288-6295.

ffrench-Constant C, Hynes RO. 1989. Alternative splicing of fibronectin is temporally and spatially regulated in the chicken embryo. Development 106: 375-388.

ffrench-Constant C, Hollingsworth A, Heasman J, Wylie CC. 1991. Response to fibronectin of mouse primordial germ cells before, during and after migration. Development 113: 1365-1373.

ffrench-Constant C, Van De Water L, Dvorak HF, Hynes RO. 1989. Reappearance of an embryonic pattern of fibronectin splicing during wound healing in the adult rat. J Cell Biol 109: 903-914.

Fogelgren B, Polgár N, Szauter KM, Ujfaludi Z, Laczkó R, Fong KS, Csiszar K. 2005. Cellular fibronectin binds to lysyl oxidase with high affinity and is critical for its proteolytic activation. J Biol Chem 280: 24690-24697.

Friedland JC, Lee MH, Boettiger D. 2009. Mechanically activated integrin switch controls $\alpha_{5} \beta_{1}$ function. Science 323: $642-644$.

Fukuda T, Yoshida N, Kataoka Y, Manabe R, MizunoHorikawa Y, Sato M, Kuriyama K, Yasui N, Sekiguchi K. 2002. Mice lacking the EDB segment of fibronectin develop normally but exhibit reduced cell growth and fibronectin matrix assembly in vitro. Cancer Res 62: 5603-5610.

Galante LL, Schwarzbauer JE. 2007. Requirements for sulfate transport and the diastrophic dysplasia sulfate transporter in fibronectin matrix assembly. J Cell Biol 179: 999-1009.

George EL, Georges-Labouesse EN, Patel-King RS, Rayburn H, Hynes RO. 1993. Defects in mesoderm, neural tube and vascular development in mouse embryos lacking fibronectin. Development 119: 1079-1091.

Georges-Labouesse EN, George EL, Rayburn H, Hynes RO. 1996. Mesodermal development in mouse embryos mutant for fibronectin. Dev Dyn 207: 145-156.

Gong Y, Mo C, Fraser SE. 2004. Planar cell polarity signalling controls cell division orientation during zebrafish gastrulation. Nature 430: 689-693.

Guan J-L, Hynes RO. 1990. Lymphoid cells recognize an alternatively spliced segment of fibronectin via the integrin receptor $\mathrm{a}_{4} \mathrm{~b}_{1}$. Cell 60: 53-61. 
Guo HB, Lee I, Kamar M, Akiyama SK, Pierce M. 2002 Aberrant $N$-glycosylation of $\beta_{1}$ integrin causes reduced $\alpha_{5} \beta_{1}$ integrin clustering and stimulates cell migration. Cancer Res 62: 6837-6845.

Halliday NL, Tomasek JJ. 1995. Mechanical properties of the extracellular matrix influence fibronectin fibril assembly in vitro. Exp Cell Res 217: 109-117.

Heasman J, Hynes RO, Swan AP, Thomas V, Wylie CC. 1981. Primordial germ cells of Xenopus embryos: The role of fibronectin in their adhesion during migration. Cell 27: 437-447.

Heisenberg CP, Tada M, Rauch GJ, Saúde L, Concha ML, Geisler R, Stemple DL, Smith JC, Wilson SW. 2000. Silberblick/Wnt11 mediates convergent extension movements during zebrafish gastrulation. Nature 405: 76-81.

Hocking DC, Sottile J, McKeown-Longo PJ. 1994. Fibronectin's III-1 module contains a conformation-dependent binding site for the amino-terminal region of fibronectin. J Biol Chem 269: 19183-19191.

Huveneers S, Truong H, Fässler R, Sonnenberg A, Danen EH. 2008. Binding of soluble fibronectin to integrin $\alpha_{5} \beta_{1}$ - Link to focal adhesion redistribution and contractile shape. J Cell Sci 121: 2452-2462.

Hynes RO. 1990. Fibronectins. Springer-Verlag, New York.

Hynes RO. 2002. Integrins: Bidirectional, allosteric signaling machines. Cell 110: 673-687.

Hynes RO. 2009. The extracellular matrix: Not just pretty fibrils. Science 326: 1216-1219.

Hynes RO, Zhao Q. 2000. The evolution of cell adhesion. J Cell Biol 150: F89-96.

Ilic D, Kovacic B, Johkura K, Schlaepfer DD, Tomasevic N, Han Q, Kim JB, Howerton K, Baumbusch C, Ogiwara $\mathrm{N}$, et al. 2004. FAK promotes organization of fibronectin matrix and fibrillar adhesions. J Cell Sci 117: 177-187.

Ingham KC, Brew SA, Erickson HP. 2004. Localization of a cryptic binding site for tenascin on fibronectin. $J$ Biol Chem 279: 28132-28135.

Ingham KC, Brew SA, Isaacs BS. 1988. Interaction of fibronectin and its gelatin-binding domains with fluorescent-labeled chains of type I collagen. J Biol Chem 263: 4624-4628.

Johnson KJ, Sage H, Briscoe G, Erickson HP. 1999. The compact conformation of fibronectin is determined by intramolecular ionic interactions. J Biol Chem 274: 15473-15479.

Joos TO, Whittaker CA, Meng F, DeSimone DW, Gnau V, Hausen P. 1995. Integrin $\alpha 5$ during early development of Xenopus laevis. Mech Dev 50: 187-199.

Jülich D, Geisler R, Holley SA, Consortium TS. 2005. Integrin $\alpha 5$ and delta/notch signaling have complementary spatiotemporal requirements during zebrafish somitogenesis. Dev Cell 8: 575-586.

Jülich D, Mould AP, Koper E, Holley SA. 2009. Control of extracellular matrix assembly along tissue boundaries via Integrin and Eph/Ephrin signaling. Development 136: $2913-2921$.

Kaczmarek J, Castellani P, Nicolo G, Spina B, Allemanni G, Zardi L. 1994. Distribution of oncofetal fibronectin isoforms in normal, hyperplastic and neoplastic human breast tissues. Int J Cancer 59: 11-16.
Karuri NW, Lin Z, Rye HS, Schwarzbauer JE. 2009. Probing the conformation of the fibronectin $\mathrm{III}_{1-2}$ domain by fluorescence resonance energy transfer. J Biol Chem 284: $3445-3452$.

Kilian O, Dahse R, Alt V, Zardi L, Hentschel J, Schnettler R, Kosmehl H. 2008. mRNA expression and protein distribution of fibronectin splice variants and high-molecular weight tenascin-C in different phases of human fracture healing. Calcif Tissue Int 83: 101-111.

Klass CM, Couchman JR, Woods A. 2000. Control of extracellular matrix assembly by syndecan-2 proteoglycan. J Cell Sci 113: 493-506.

Koukoulis GK, Howeedy MK, Korhen M, Virtanen I, Gould VE. 1993. Distribution of tenascin, cellular fibronectins and integrins in the normal, hyperplastic, and neoplastic breast. J Submicrosc Cytol Pathol 25: 285-295.

Kragtorp KA, Miller JR. 2006. Regulation of somitogenesis by Ena/VASP proteins and FAK during Xenopus development. Development 133: 685-695.

Kragtorp KA, Miller JR. 2007. Integrin $\alpha_{5}$ is required for somite rotation and boundary formation in Xenopus. Dev Dyn 236: 2713-2720.

Kramer KL, Yost HJ. 2002. Ectodermal syndecan-2 mediates left-right axis formation in migrating mesoderm as a cell-nonautonomous Vg1 cofactor. Dev Cell 2: 115-124.

Krotoski DM, Domingo C, Bronner-Fraser M. 1986. Distribution of a putative cell surface receptor for fibronectin and laminin in the avian embryo. J Cell Biol 103: 1061-1071.

Kumazaki T, Mitsui Y, Hamada K, Sumida H, Nishiyama M. 1999. Detection of alternative splicing of fibronectin mRNA in a single cell. J Cell Sci 112: 1449-1453.

Langenbach KJ, Sottile J. 1999. Identification of proteindisulfide isomerase activity in fibronectin. $J$ Biol Chem 274: 7032-7038.

Latimer A, Jessen JR. 2010. Extracellular matrix assembly and organization during zebrafish gastrulation. Matrix Biol 29: 89-96.

Leahy DJ, Aukhil I, Erickson HP. 1996. 2.0 A crystal structure of a four-domain segment of human fibronectin encompassing the RGD loop and synergy region. Cell 84: 155-164.

Leahy DJ, Hendrickson WA, Aukhil I, Erickson HP. 1992. Structure of a fibronectin type III domain from tenascin phased by MAD analysis of the selenomethionyl protein. Science 258: 987-991.

Lecuit T, Lenne P-F. 2007. Cell surface mechanics and the control of cell shape, tissue patterns and morphogenesis. Nat Rev Mol Cell Biol 8: 633-644.

Lee G, Hynes R, Kirschner M. 1984. Temporal and spatial regulation of fibronectin in early Xenopus development. Cell 36: 729-740.

Liao YF, Gotwals PJ, Koteliansky VE, Sheppard D, Van De Water L. 2002. The EIIIA segment of fibronectin is a ligand for integrins $\alpha_{9} \beta_{1}$ and $\alpha_{4} \beta_{1}$ providing a novel mechanism for regulating cell adhesion by alternative splicing. J Biol Chem 277: 14467-14474.

Litvinovich SV, Brew SA, Aota S, Akiyama SK, Haudenschild C, Ingham KC. 1998. Formation of amyloid-like fibrils by self-association of a partially unfolded fibronectin type III module. J Mol Biol 280: 245-258. 
MacLeod JN, Burton-Wurster N, Gu DN, Lust G. 1996 Fibronectin mRNA splice variant in articular cartilage lacks bases encoding the V, III-15, and I-10 protein segments. J Biol Chem 271: 18954-18960.

Main AL, Harvey TS, Baron M, Boyd J, Campbell ID. 1992. The three-dimensional structure of the tenth type III module of fibronectin: An insight into RGD-mediated interactions. Cell 71: 671-678.

Manabe R, Oh-e N, Maeda T, Fukuda T, Sekiguchi K. 1997. Modulation of cell-adhesive activity of fibronectin by the alternatively spliced EDA segment. J Cell Biol 139: 295-307.

Mao Y, Schwarzbauer JE. 2005. Fibronectin fibrillogenesis, a cell-mediated matrix assembly process. Matrix Biol 24: 389-399.

Maqueda A, Moyano JV, Hernández Del Cerro M, Peters DM, Garcia-Pardo A. 2007. The heparin III-binding domain of fibronectin ( $\mathrm{III}_{4-5}$ repeats) binds to fibronectin and inhibits fibronectin matrix assembly. Matrix Biol 26: 642-651.

Marsden M, DeSimone DW. 2001. Regulation of cell polarity, radial intercalation and epiboly in Xenopus: Novel roles for integrin and fibronectin. Development 128: 3635-3647.

Marsden M, DeSimone DW. 2003. Integrin-ECM interactions regulate cadherin-dependent cell adhesion and are required for convergent extension in Xenopus. Curr Biol 13: 1182-1191.

Matsuura H, Takio K, Titani K, Greene T, Levery SB, Salyan ME, Hakomori S. 1988. The oncofetal structure of human fibronectin defined by monoclonal antibody FDC-6. Unique structural requirement for the antigenic specificity provided by a glycosylhexapeptide. J Biol Chem 263: 3314-3322.

McBeath R, Pirone DM, Nelson CM, Bhadriraju K, Chen CS. 2004. Cell shape, cytoskeletal tension, and RhoA regulate stem cell lineage commitment. Dev Cell 6: 483-495.

McDonald JA. 1988. Extracellular matrix assembly. Annu Rev Cell Biol 4: 183-207.

McDonald JA, Quade BJ, Broekelman TJ, LaChance R, Forsman K, Hasegawa E, Akiyama S. 1987. Fibronectin's cell-adhesive domain and an amino-terminal matrix assembly domain participate in its assembly into fibroblast pericellular matrix. J Biol Chem 262: 2957-2967.

McKeown-Longo PJ, Mosher DF. 1983. Binding of plasma fibronectin to cell layers of human skin fibroblasts. $J$ Cell Biol 97: 466-472.

McKeown-Longo PJ, Mosher DF. 1985. Interaction of the 70,000-mol. wt. amino terminal fragment of fibronectin with matrix-assembly receptor of fibroblasts. J Cell Biol 100: $364-374$.

Moretti FA, Chauhan AK, Iaconcig A, Porro F, Baralle FE, Muro AF. 2007. A major fraction of fibronectin present in the extracellular matrix of tissues is plasma-derived. J Biol Chem 282: 28057-28062.

Morgan MR, Humphries MJ, Bass MD. 2007. Synergistic control of cell adhesion by integrins and syndecans. Nature Rev Mol Cell Biol 8: 957-969.

Morla A, Ruoslahti E. 1992. A fibronectin self-assembly site involved in fibronectin matrix assembly: Reconstruction in a synthetic peptide. J Cell Biol 118: 421-429.
Morla A, Zhang Z, Ruoslahtl E. 1994. Superfibronectin is a functionally distinct form of fibronectin. Nature 367: 193-196.

Mosher DF. 1975. Cross-linking of cold-insoluble globulin by fibrin stabilizing factor. J Biol Chem 260: 6614-6621.

Mosher DF, ed. 1989. Fibronectin. Academic Press, New York.

Mostafavi-Pour Z, Askari JA, Whittard JD, Humphries MJ. 2001. Identification of a novel heparin-binding site in the alternatively spliced IIICS region of fibronectin: Roles of integrins and proteoglycans in cell adhesion to fibronectin splice variants. Matrix Biol 20: 63-73.

Mould AP, Komoriya A, Yamada KM, Humphries MJ. 1991. The CS5 peptide is a second site in the IIICS region of fibronectin recognized by the integrin $\alpha_{4} \beta_{1}$ : Inhibition of $\alpha_{4} \beta_{1}$ function by RGD peptide homologues. J Biol Chem 266: 3579-3585.

Muñoz R, Moreno M, Oliva C, Orbenes C, Larraín J. 2006. Syndecan-4 regulates non-canonical Wnt signalling and is essential for convergent and extension movements in Xenopus embryos. Nat Cell Biol 8: 492-500.

Muro AF, Chauhan AK, Gajovic S, Iaconcig A, Porro F, Stanta G, Baralle FE. 2003. Regulated splicing of the fibronectin EDA exon is essential for proper skin wound healing and normal lifespan. J Cell Biol 162: 149-160.

Nagai T, Yamakawa N, Aota S, Yamada SS, Akiyama SK, Olden K, Yamada KM. 1991. Monoclonal antibody characterization of two distant sites required for function of the central cell-binding domain of fibronectin in cell adhesion, cell migration, and matrix assembly. J Cell Biol 114: 1295-1305.

Nagel M, Winklbauer R. 1999. Establishment of substratum polarity in the blastocoel roof of the Xenopus embryo. Development 126: 1975-1984.

Nagel M, Tahinci E, Symes K, Winklbauer R. 2004. Guidance of mesoderm cell migration in the Xenopus gastrula requires PDGF signaling. Development 131: 2727-2736.

Nakatsuji N, Johnson KE. 1983. Conditioning of a culture substratum by the ectodermal layer promotes attachment and oriented locomotion by amphibian gastrula mesodermal cells. J Cell Sci 59: 43-60

Nakatsuji N, Johnson KE. 1984. Experimental manipulation of a contact guidance system in amphibian gastrulation by mechanical tension. Nature 307: $453-5$

Nakatsuji N, Gould AC, Johnson KE. 1982. Movement and guidance of migrating mesodermal cells in Ambystoma maculatum gastrulae. J Cell Sci 56: 207-222.

Nojima Y, Humphries MJ, Mould AP, Komoriya A, Yamada KM, Schlossman SF, Morimoto C. 1990. VLA-4 mediates $\mathrm{CD} 3$-dependent $\mathrm{CD} 4^{+} \mathrm{T}$ cell activation via the $\mathrm{CS} 1$ alternatively spliced domain of fibronectin. J Exp Med 172: 1185-92

Norton PA, Hynes RO. 1987. Alternative splicing of chicken fibronectin in embryos and in normal and transformed cells. Mol Cell Biol 7: 4297-4307.

Ohashi T, Erickson HP. 2005. Domain unfolding plays a role in superfibronectin formation. $J$ Biol Chem 280: 39143-39151.

Ohashi T, Erickson HP. 2009. Revisiting the mystery of fibronectin multimers: The fibronectin matrix is composed of 
fibronectin dimers cross-linked by non-covalent bonds. Matrix Biol 28: 170-175.

Ohashi T, Kiehart DP, Erickson HP. 1999. Dynamics and elasticity of the fibronectin matrix in living cell culture visualized by fibronectin-green fluorescent protein. Proc Natl Acad Sci 96: 2153-2158.

Ohashi T, Kiehart DP, Erickson HP. 2002. Dual labeling of the fibronectin matrix and actin cytoskeleton with green fluorescent protein variants. J Cell Sci 115: 1221-1229.

Olorundare OE, Peyruchaud O, Albrecht RM, Mosher DF. 2001. Assembly of a fibronectin matrix by adherent platelets stimulated by lysophosphatidic acid and other agonists. Blood 98: 117-124.

Onodera T, Sakai T, Hsu JC-f, Matsumoto K, Chiorini JA, Yamada KM. 2010. Btbd7 regulates epithelial cell dynamics and branching morphogenesis. Science 329: 562-565.

Oyama F, Hirohashi S, Sakamoto M, Titani K, Sekiguchi K. 1993. Coordinate oncodevelopmental modulation of alternative splicing of fibronectin pre-messenger RNA at $\mathrm{ED}-\mathrm{A}, \mathrm{ED}-\mathrm{B}$, and CS1 regions in human liver tumors. Cancer Res 53: 2005-2011.

Oyama F, Murata Y, Suganuma N, Kimura T, Titani K, Sekiguchi K. 1989. Patterns of alternative splicing of fibronectin pre-mRNA in human adult and fetal tissues. Biochemistry 28: 1428-1434.

Pagani F, Zagato L, Vergani C, Casari G, Sidoli A, Baralle FE. 1991. Tissue-specific splicing pattern of fibronectin messenger RNA precursor during development and aging in rat. J Cell Biol 113: 1223-1229.

Palecek SP, Loftus JC, Ginsberg MH, Lauffenburger DA, Horwitz AF. 1997. Integrin-ligand binding properties govern cell-substratum adhesiveness. Nature 385: 537 540.

Pankov R, Yamada KM. 2002. Fibronectin at a glance. J Cell Sci 115: 3861-3863.

Pankov R, Cukierman E, Katz BZ, Matsumoto K, Lin DC, Hahn C, Yamada KM. 2000. Integrin dynamics and matrix assembly: Tensin-dependent translocation of $\alpha_{5} \beta_{1}$ integrins promotes early fibronectin fibrillogenesis. J Cell Biol 148: 1075-1090.

Paszek MJ, Zahir N, Johnson KR, Lakins JN, Rozenberg GI, Gefen A, Reinhart-King CA, Margulies SS, Dembo M, Boettiger D, et al. 2005. Tensional homeostasis and the malignant phenotype. Cancer Cell 8: 241-254.

Peters J, Sechrist J, Luetolf S, Loredo G, Bronner-Fraser M. 2002. Spatial expression of the alternatively spliced EIIIB and EIIIA segments of fibronectin in the early chicken embryo. Cell Commun Adhes 9: 221-238.

Petersen TE, Thogersen HC, Skorstengaard K, VibePedersen K, Sahl P, Sottrup-Jensen L, Magnusson S. 1983. Partial primary structure of bovine plasma fibronectin: Three types of internal homology. Proc Natl Acad Sci 80: 137-141.

Pierschbacher MD, Ruoslahti E. 1984. Cell attachment activity of fibronectin can be duplicated by small synthetic fragments of the molecule. Nature 309: 30-33.

Radek JT, Jeong J-M, Prasanna Murthy SN, Ingham K, Lorand L. 1993. Affinity of human erythrocyte transglutaminase for a $42-\mathrm{kDa}$ gelatin-binding fragment of human plasma fibronectin. Proc Natl Acad Sci 90: 3152-3156.
Reintsch WE, Hausen P. 2001. Dorsoventral differences in cell-cell interactions modulate the motile behaviour of cells from the Xenopus gastrula. Dev Biol 240: 387-403.

Rovasio RA, Delouvee A, Yamada KM, Timpl R, Thiery JP. 1983. Neural crest cell migration: Requirements for exogenous fibronectin and high cell density. J Cell Biol 96: $462-473$.

Rozario T, DeSimone DW. 2010. The extracellular matrix in development and morphogenesis: A dynamic view. Dev Biol 341: 126-140.

Rozario T, Dzamba B, Weber G, Davidson L, Desimone D. 2009. The physical state of fibronectin matrix differentially regulates morphogenetic movements in vivo. $\mathrm{Dev}$ Biol 327: 386-398.

Rubin GM, Yandell MD, Wortman JR, Gabor Miklos GL, Nelson CR, Hariharan IK, Fortini ME, Li PW, Apweiler R, Fleischmann W, et al. 2000. Comparative genomics of the eukaryotes. Science 287: 2204-2215.

Sabatier L, Chen D, Fagotto-Kaufmann C, Hubmacher D, McKee MD, et al. 2009. Fibrillin assembly requires fibronectin. Mol Biol Cell 20: 846-858.

Sakai T, Larsen M, Yamada KM. 2003. Fibronectin requirement in branching morphogenesis. Nature 423: 876-881.

Sanders EJ. 1982. Ultrastructural immunocytochemical localization of fibronectin in the early chick embryo. $J$ Embryol Exp Morphol 71: 155-170.

Santas AJ, Peterson JA, Halbleib JL, Craig SE, Humphries MJ, Peters DM. 2002. Alternative splicing of the IIICS domain in fibronectin governs the role of the heparin II domain in fibrillogenesis and cell spreading. $J$ Biol Chem 277: 13650-13658.

Saunders S, Bernfield M. 1988. Cell surface proteoglycan binds mouse mammary epithelial cells to fibronectin and behaves as a receptor for interstitial matrix. $J$ Cell Biol 106: 423-430.

Schofield KP, Humphries MJ. 1999. Identification of fibronectin IIICS variants in human bone marrow stroma. Blood 93: 410-411.

Schwarz-Linek U, Höök M, Potts JR. 2006. Fibronectinbinding proteins of gram-positive cocci. Microbes Infect 8: $2291-2298$.

Schwarzbauer JE. 1991a. Fibronectin: From gene to protein. Curr Opin Cell Biol 3: 786-791.

Schwarzbauer JE. 1991b. Identification of the fibronectin sequences required for assembly of a fibrillar matrix. $J$ Cell Biol 113: 1463-1473.

Schwarzbauer JE, Spencer CS, Wilson CL. 1989. Selective secretion of alternatively spliced fibronectin variants. J Cell Biol 109: 3445-3453.

Schwarzbauer JE, Patel RS, Fonda D, Hynes RO. 1987. Multiple sites of alternative splicing of the rat fibronectin gene transcript. EMBO J 6: 2573-2580.

Schwarzbauer JE, Tamkun JW, Lemischka IR, Hynes RO. 1983. Three different fibronectin mRNAs arise by alternative splicing within the coding region. Cell 35: 421-431.

Sechler JL, Corbett SA, Schwarzbauer JE. 1997. Modulatory roles for integrin activation and the synergy site of fibronectin during matrix assembly. Mol Biol Cell 8: $2563-2573$. 
Sechler JL, Cumiskey AM, Gazzola DM, Schwarzbauer JE 2000. A novel RGD-independent fibronectin assembly pathway initiated by $\alpha_{4} \beta_{1}$ integrin binding to the alternatively spliced V region. J Cell Sci 113: 1491-1498.

Sechler JL, Rao H, Cumiskey AM, Vega-Colon I, Smith MS, et al. 2001. A novel fibronectin binding site required for fibronectin fibril growth during matrix assembly. J Cell Biol 154: 1081-1088.

Sechler JL, Takada Y, Schwarzbauer JE. 1996. Altered rate of fibronectin matrix assembly by deletion of the first type III repeats. J Cell Biol 134: 573-583.

Shi DL, Delarue M, Darribere T, Riou JF, Boucaut J-C. 1987. Experimental analysis of the extension of the dorsal marginal zone in Pleurodeles walt gastrulae. Development 100: $147-161$.

Singh P, Carraher C, Schwarzbauer JE. 2010. Assembly of fibronectin extracellular matrix. Annu Rev Cell Dev Biol 26: $397-419$.

Smith ML, Gourdon D, Little WC, Kubow KE, Eguiluz RA, Luna-Morris S, Vogel V. 2007. Force-induced unfolding of fibronectin in the extracellular matrix of living cells. PLoS Biol 5: e268.

Somers CE, Mosher DF. 1993. Protein kinase C modulation of fibronectin matrix assembly. $J$ Biol Chem 268: 22277-22280.

Sottile J, Schwarzbauer JE, Selegue J, Mosher DF. 1991. Five type I modules of fibronectin form a functional unit that binds to fibroblasts and Staphylococcus aureus. J Biol Chem 266: 12840-12843.

Stepp MA, Daley WP, Bernstein AM, Pal-Ghosh S, Tadvalkar G, Shashurin A, Palsen S, Jurjus RA, Larsen M. 2010 Syndecan-1 regulates cell migration and fibronectin fibril assembly. Exp Cell Res 316: 2322-2339.

Strøm EH, Banfi G, Krapf R, Abt AB, Mazzucco G, Monga G, Gloor F, Neuweiler J, Riess R, Stosiek P, et al. 1995. Glomerulopathy associated with predominant fibronectin deposits: A newly recognized hereditary disease. Kidney Int 48: 163-170.

Takahashi S, Leiss M, Moser M, Ohashi T, Kitao T, Heckmann D, Pfeifer A, Kessler H, Takagi J, Erickson HP, et al. 2007. The RGD motif in fibronectin is essential for development but dispensable for fibril assembly. J Cell Biol 178: 167-178.

Tan MH, Sun Z, Opitz SL, Schmidt TE, Peters JH, George EL. 2004. Deletion of the alternatively spliced fibronectin EIIIA domain in mice reduces atherosclerosis. Blood 104: $11-18$.

Trefzer U, Chen Y, Herberth G, Hofmann MA, Kiecker F, Guo Y, Sterry W. 2006. The monoclonal antibody SM5-1 recognizes a fibronectin variant whcih is widely expressed in melanoma. BMC Cancer 6: 8 .

Trinh LA, Stainier DYR. 2004. Fibronectin regulates epithelial organization during myocardial migration in zebrafish. Dev Cell 6: 371-382.

Tsyguelnaia I, Doolittle RF. 1998. Presence of a fibronectin type III domain in a plant protein. J Mol Evol 46: 612-614.

Tucker RP, Chiquet-Ehrismann R. 2009. Evidence for the evolution of tenascin and fibronectin early in the chordate lineage. Int J Biochem Cell Biol 41: 424-434.
Ulrich F, Krieg M, Schötz E-M, Link V, Castanon I, Schnabel V, Taubenberger A, Mueller D, Puech PH, Heisenberg CP. 2005. Wnt11 functions in gastrulation by controlling cell cohesion through Rab5c and E-cadherin. Dev Cell 9: $555-564$.

Vakonakis I, Staunton D, Rooney LM, Campbell ID. 2007. Interdomain association in fibronectin: Insight into cryptic sites and fibrillogenesis. EMBO J 26: 2575-2783.

Van Vliet A, Baelde HJ, Vleming LJ, de Heer E, Bruijn JA. 2001. Distribution of fibronectin isoforms in human renal disease. J Pathol 193: 256-262.

Ventura E, Sassi F, Parodi A, Balza E, Borsi L, Castellani P, Carnemolla B, Zardi L. 2010. Alternative splicing of the angiogenesis associated extra-domain $\mathrm{B}$ of fibronectin regulates the accessibility of the B-C loop of the type III repeat 8. PLoS One 5: e9145.

Wallingford JB, Rowning BA, Vogeli KM, Rothbächer U, Fraser SE, Harland RM. 2000. Dishevelled controls cell polarity during Xenopus gastrulation. Nature 405: 81-85.

Wayner EA, Garcia-Pardo A, Humphries MJ, McDonald JA, Carter WG. 1989. Identification and characterization of the $\mathrm{T}$ lymphocyte adhesion receptor for an alternative cell attachment domain (CS-1) in plasma fibronectin. J Cell Biol 109: 1321-1330.

Wei Y, Mikawa T. 2000. Formation of the avian primitive streak from spatially restricted blastoderm: Evidence for polarized cell division in the elongating streak. Development 127: 87-96.

Wennerberg K, Lohikangas L, Gullberg D, Pfaff M, Johansson S, Fassler R. 1996. $\beta_{1}$ integrin-dependent and -independent polymerization of fibronectin. J Cell Biol 132: 227-238.

Whittaker CA, Bergeron K-F, Whittle J, Brandhorst BP, Burke RD, Hynes RO. 2006. The echinoderm adhesome. Dev Biol 300: 252-266.

Wierzbicka-Patynowski I, Schwarzbauer JE. 2002. Regulatory role for Src and phosphatidylinositol 3-kinase in initiation of fibronectin matrix assembly. $\mathrm{J}$ Biol Chem 277: 19703-19708.

Wierzbicka-Patynowski I, Schwarzbauer JE. 2003. The ins and outs of fibronectin matrix assembly. J Cell Sci 116: 3269-3276.

Wierzbicka-Patynowski I, Mao Y, Schwarzbauer JE. 2007. Continuous requirement for pp60-Src and phosphopaxillin during fibronectin matrix assembly by transformed cells. J Cell Physiol 210: 750-756.

Wilson CL, Schwarzbauer JE. 1992. The alternatively spliced $\mathrm{V}$ region contributes to the differential incorporation of plasma and cellular fibronectins into fibrin clots. J Cell Biol 119: 923-933.

Winklbauer R. 1998. Conditions for fibronectin fibril formation in the early Xenopus embryo. Dev Dyn 212: $335-345$.

Winklbauer R, Keller RE. 1996. Fibronectin, mesoderm migration, and gastrulation in Xenopus. Dev Biol 177: 413-426.

Winklbauer R, Nagel M, Selchow A, Wacker S. 1996. Mesoderm migration in the Xenopus gastrula. Int J Dev Biol 40: 305-311. 
Winklbauer R, Selchow A, Nagel M, Angres B. 1992. Cell interaction and its role in mesoderm cell migration during Xenopus gastrulation. Dev Dyn 195: 290-302.

Woods A, Couchman JR. 1998. Syndecans: Synergistic activators of cell adhesion. Trends Cell Biol 8: 189-194.

Woods A, Longley RL, Tumova S, Couchman JR. 2000. Syndecan- 4 binding to the high affinity heparin-binding domain of fibronectin drives focal adhesion formation in fibroblasts. Arch Biochem Biophys 374: 66-72.

Wu C, Bauer JS, Juliano RL, McDonald JA. 1993. The $\alpha_{5} \beta_{1}$ integrin fibronectin receptor, but not the $\alpha_{5}$ cytoplasmic domain, functions in an early and essential step in fibronectin matrix assembly. J Biol Chem 268: 21883-21888.

Wu C, Hughes PE, Ginsberg MH, McDonald JA. 1996. Identification of a new biological function for the integrin $\alpha_{\mathrm{v}} \beta_{3}$ : Initiation of fibronectin matrix assembly. Cell Adhes Commun 4: 149-158.

Yang JT, Hynes RO. 1996. Fibronectin receptor functions in embryonic cells deficient in $\alpha_{5} \beta_{1}$ integrin can be replaced by $\alpha_{v}$ integrins. Mol Biol Cell 7: 1737-1748.

Yang JT, Rayburn H, Hynes RO. 1993. Embryonic mesodermal defects in $\alpha_{5}$ integrin-deficient mice. Development 119: $1093-1105$.

Yoneda A, Multhaupt HAB, Couchman JR. 2005. The Rho kinases I and II regulate different aspects of myosin II activity. J Cell Biol 170: 443-453.

Yoneda A, Ushakov D, Multhaupt HA, Couchman JR. 2007. Fibronectin matrix assembly requires distinct contributions from Rho kinases I and -II. Mol Biol Cell 18: 66-75.
Zamir EA, Czirók A, Cui C, Little CD, Rongish BJ. 2006. Mesodermal cell displacements during avian gastrulation are due to both individual cell-autonomous and convective tissue movements. Proc Natl Acad Sci 103: 19806-19811.

Zardi L, Carnemolla B, Siri A, Petersen TE, Paolella G, Sebastio G, Baralle FE. 1987. Transformed human cells produce a new fibronectin isoform by preferential alternative splicing of a previously unobserved exon. $E M B O$ J 6: $2337-2342$.

Zhang Q, Checovich WJ, Peters DM, Albrecht RM, Mosher DF. 1994. Modulation of cell surface fibronectin assembly sites by lysophosphatidic acid. J Cell Biol 127: 1447-1459.

Zhang Q, Magnusson MK, Mosher DF. 1997. Lysophosphatidic acid and microtubule-destabilizing agents stimulate fibronectin matrix assembly through Rho-dependent actin stress fiber formation and cell contraction. Mol Biol Cell 8: 1415-1425.

Zhang Z, Morla AO, Vuori K, Bauer JS, Juliano RL, Ruoslahti E. 1993. The avb1 integrin functions as a fibronectin receptor but does not support fibronectin matrix assembly and cell migration on fibronectin. J Cell Biol 122: $235-242$.

Zhong C, Chrzanowska-Wodnicka M, Brown J, Shaub A, Belkin AM, Burridge K. 1998. Rho-mediated contractility exposes a cryptic site in fibronectin and induces fibronectin matrix assembly. J Cell Biol 141: 539-551. 


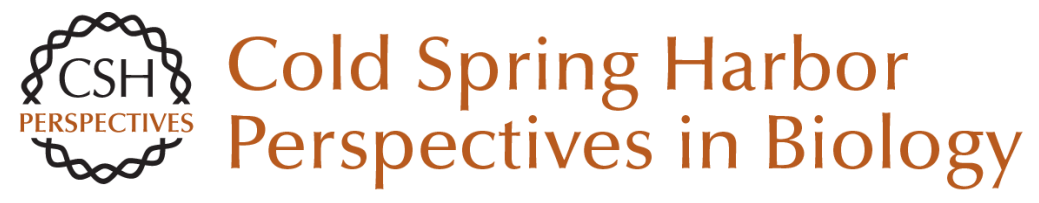

\section{Fibronectins, Their Fibrillogenesis, and In Vivo Functions}

Jean E. Schwarzbauer and Douglas W. DeSimone

Cold Spring Harb Perspect Biol 2011; doi: 10.1101/cshperspect.a005041 originally published online May 16, 2011

\section{Subject Collection Extracellular Matrix Biology}

Extracellular Matrix in Development: Insights from Mechanisms Conserved between Invertebrates and Vertebrates Nicholas H. Brown

Extracellular Matrix Proteins in Hemostasis and Thrombosis Wolfgang Bergmeier and Richard O. Hynes

The Thrombospondins Josephine C. Adams and Jack Lawler

Cross Talk among TGF- $\beta$ Signaling Pathways, Integrins, and the Extracellular Matrix John S. Munger and Dean Sheppard

Heparan Sulfate Proteoglycans Stephane Sarrazin, William C. Lamanna and Jeffrey D. Esko

The Collagen Family Sylvie Ricard-Blum

Tenascins and the Importance of Adhesion Modulation

Ruth Chiquet-Ehrismann and Richard P. Tucker

Integrin Structure, Activation, and Interactions

lain D. Campbell and Martin J. Humphries
Extracellular Matrix Degradation and Remodeling in Development and Disease

Pengfei Lu, Ken Takai, Valerie M. Weaver, et al.

Overview of the Matrisome--An Inventory of Extracellular Matrix Constituents and Functions Richard O. Hynes and Alexandra Naba

Integrins in Cell Migration Anna Huttenlocher and Alan Rick Horwitz

Fibronectins, Their Fibrillogenesis, and In Vivo

Functions Jean E. Schwarzbauer and Douglas W. DeSimone

Extracellular Matrix: Functions in the Nervous System

Claudia S. Barros, Santos J. Franco and Ulrich Müller

Molecular Architecture and Function of Matrix

Adhesions

Benjamin Geiger and Kenneth M. Yamada

Cell-Extracellular Matrix Interactions in Normal and Diseased Skin

Fiona M. Watt and Hironobu Fujiwara

Genetic Analyses of Integrin Signaling

Sara A. Wickström, Korana Radovanac and Reinhard Fässler

For additional articles in this collection, see http://cshperspectives.cshlp.org/cgi/collection/

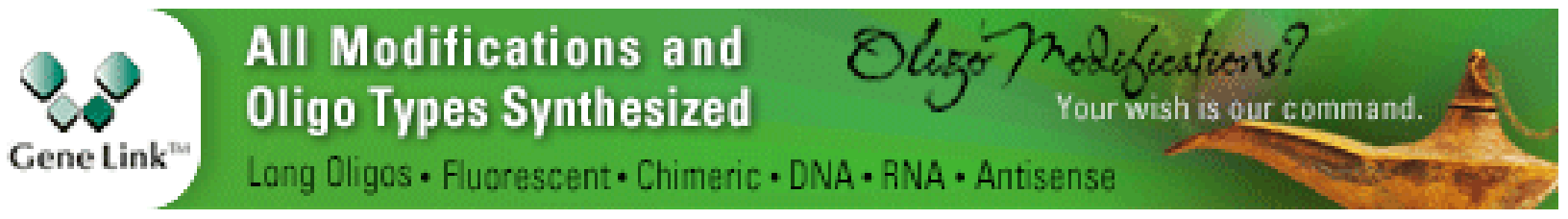

